\title{
Perception towards Male Enrolment in Nursing among High School Students at Selected Schools of Bharatpur, Chitwan
}

\author{
Ramesh Subba ${ }^{1}$, Hem Kumari Subba ${ }^{2}$, Alisha Joshi ${ }^{1}$, Amrita Ghimire ${ }^{1}$, \\ Sarita Nepal ${ }^{1}$, Jaya Prasad Singh ${ }^{3}$
}

${ }^{1}$ Department of Psychiatric Nursing, School of Nursing, Chitwan Medical College, Bharatpur-10, Nepal
${ }^{2}$ Department of Adult Health Nursing, School of Nursing, Chitwan Medical College, Bharatpur-10, Nepal
${ }^{3}$ Department of Community Medicine, School of Nursing, Chitwan Medical College, Bharatpur-10, Nepal

Corresponding Author: Hem Kumari Subba

\begin{abstract}
Nursing profession has been a gender lopsided profession which has limited the opportunity for male students to prefer nursing as career choices. However, the perception of male enrolment in nursing among the students is extremely important to maintain the diversity in nursing workforce. This study aimed to assess the perception towards male enrolment in nursing among the students at selected schools of Bharatpur, Chitwan. A cross-sectional survey design consisted of 222 students studying in private and government schools of Chitwan districts. Samples were selected purposively and selfadministered structured questionnaire containing of 28 items for perception of male enrolment in nursing were used to collect data. Collected data were analysed using descriptive and inferential statistics. Majority of participants $(54.5 \%)$ showed positive perception towards male enrolment in nursing whereas less than half $(45.5 \%)$ showed negative perception towards male enrolment in nursing. The result indicated that perception towards male enrolment was not significantly associated with socio demographic variables. Despite having a positive notion about male in nursing, considerable number of participants were negative about male in nursing. The hiring and maintaining of male nurses in the nursing field is a very apparent issue nowadays. Therefore, this indicates the urgent need by concerning authorities in identifying the predictors in improving the professional nursing image and misconceptions regarding the gender based profession for better health care outcomes.
\end{abstract}

Key Words: Perception, Male enrolment, Nursing

\section{INTRODUCTION}

Nursing is a dynamic profession and an integral part of health care system. ${ }^{1}$ The profession has growing demand worldwide and load of challenges of which attraction of male students to become a nurse is an important concern. ${ }^{2,3}$ Nursing is traditionally dominated female profession ${ }^{4,5}$ despite the progress made by women into male dominated professions such as business or medicine. ${ }^{6}$ Nursing has been portrayed as a feminine occupation ever since the appearance of Nightingale nursing training in the mid-nineteenth century which favoured women over men. ${ }^{7}$ The perception that nursing is inherently appropriate for women might deter the applicants from seeking the admission to the nursing programs. $^{6}$ The historiography of the nursing profession has significant issue to attract male membership due to various female dominant positions ${ }^{8,9}$ Nowadays, In various countries male nurses have been studying in nursing schools and developing a career traditionally female. ${ }^{8}$ In Nepal, the patriarchal cultures lead to the discontinuation of male enrolment in nursing after training 80 males from 
Tribhuvan University in the past. ${ }^{10}$ The public perception of nursing exclusive to females is well entrenched societal belief that might influence younger generation to resist their interest in choosing nursing career. ${ }^{11}$ However, perceiving the importance of recruiting male nurse, Nepal nursing council has issued notice regarding the inclusion of $15 \%$ of male students in June $2018^{12}$ and estimating 1000 male nurse graduates by $2021 .{ }^{13}$ Perception is highly subjective and usually not based on the facts that greatly influence choosing nursing as a career especially among younger generation. It could be a well-planned strategy to change the perception of high school students towards nursing and its career perspectives. In this context, understanding the perception is the primary part in enrolling the male students to adopt career in nursing. Hence, this study aimed at assessing the perception towards enrolment of male in nursing among high school students at selected schools of Bharatpur, Chitwan.

\section{MATERIALS AND METHODS}

A cross-sectional survey was conducted at selected schools of Chitwan i.e. Narayani Namuna Madhyamik Bidhyalaya, Balmiki Sikshya Sadhan. There were 222 students studying in the selected schools where 113 were from Narayani Namuna Madhyamik Bidhyalaya and 109 were from Balmiki Sikshya Sadhan. Nonprobability purposive sampling technique was used as the study sample for study. Structured self-administered questionnaire was developed based on the prior literature that related to the male enrolment in nursing $9,14,15$ and consulting various experts in the field of nursing. In total, there were 40 items at the beginning and after the consultation with the experts, pre-testing the tool, 12 items were removed from the questionnaire. Each item was rated on a five-point scale (1=strongly disagree; 2=disagree; 3= Neutral; 4= Agree; 5= strongly Agree). Higher scores indicated positive perception towards the male enrolment in nursing. Pretesting of the instrument was done in Prerana English boarding school, Bharatpur among 34 students. To verify the reliability of the instrument, Cronbach's alpha was calculated using the pilot study data and the resultant Cronbach's alpha for the instrument was 0.566 indicating that the tool was reliable for further study.

Ethical clearance was obtained from the Chitwan Medical College Institutional Review Committee (Ref: CMCIRC/077/078-095). Administrative approval for data collection was obtained from the concerned authority of each school. Data was collected from 15/01/2021 to $15 / 02 / 2021$ by researchers themselves. Date and time of data collection was set on mutual plan consulting with their class coordinators and informed to all participants. Written informed consent was taken from each participant prior to data collection. Obtained data were analysed in IBM SPSS version 20 for window using descriptive as well as inferential analysis. Chi-square test was used to measure the association between levels of perception towards male enrolment and selected variables.

\section{RESULTS}

Out of 222 the median age was 17 years (Range: $15-20$ years). Majority of them were female $(58.1 \%)$, belonged to Hindu religion $(91.4 \%)$, and $76.1 \%$ were Brahmin and Chhetri. More than half $(50.9 \%)$ of respondents' were from government school and $70.3 \%$ studied in $12^{\text {th }}$ standard. Majority of the respondents' $(73.0 \%)$ resided in metropolitan/ submetropolitan city. [Table 1]

Regarding respondents' parents related information, almost all (96.4\%) respondents' father were literate ,46.7\% studied up to bachelors and above and more than half $(50.8 \%)$ were self employed. Almost all $(92.3 \%)$ of respondents' mother were literate, $59.0 \%$ studied up to secondary level and majority (80.6\%) were self employed. [Table 2] 
Ramesh Subba et.al. Perception towards male enrolment in nursing among high school students at selected schools of Bharatpur, Chitwan.

Table 1. Respondent's Socio demographic Information, $\mathbf{n = 2 2 2}$ \begin{tabular}{|l|l|l|}
\hline Variables & Frequency & Percentage \\
\hline Age & \\
\hline
\end{tabular}

\begin{tabular}{|l|l|l|}
\hline Age (in years) & & \\
\hline$<17$ & 44 & 19.8 \\
\hline$>=17$ & 178 & 80.2 \\
\hline
\end{tabular}

Median age $=17$ years, $I Q R=Q 3-Q 1=18-17, \quad$ minimum $=15$, maximum $=20$

\begin{tabular}{|l|l|l|}
\hline Sex & & \\
\hline Male & 93 & 41.9 \\
\hline Female & 129 & 58.1 \\
\hline Religion & & \\
\hline Hinduism & 203 & 91.4 \\
\hline Buddhism & 14 & 6.3 \\
\hline Islam & 4 & 1.8 \\
\hline Christian & 1 & 0.5 \\
\hline Ethnicity & & \\
\hline Brahmin/Chhetri & 169 & 76.1 \\
\hline Janjati & 26 & 11.7 \\
\hline Others & 27 & 12.2 \\
\hline Types of school & & \\
\hline Private school & 109 & 49.1 \\
\hline Government school & 113 & 50.9 \\
\hline Standard & & \\
\hline 11th standard & 66 & 29.7 \\
\hline 12th standard & 156 & 70.3 \\
\hline Place of residence & & \\
\hline Rural Municipality & 19 & 8.6 \\
\hline Municipality/Sub Municipality & 41 & 18.4 \\
\hline $\begin{array}{c}\text { Metropolitan/Sub Metropolitan } \\
\text { city }\end{array}$ & 162 & 73.0 \\
\hline
\end{tabular}

Table 2. Respondents' Parents related Information, $\mathrm{n}=222$

\begin{tabular}{|l|l|l|}
\hline Variables & Frequency & Percentage \\
\hline Father's educational status & & \\
\hline Literate & 214 & 96.4 \\
\hline Illiterate & 8 & 3.6 \\
\hline Father's level of education(n=214) & & \\
\hline Basic level & 23 & 10.7 \\
\hline Secondary level & 91 & 42.5 \\
\hline Bachelor and above & 100 & 46.7 \\
\hline Father's occupation & & \\
\hline Self employed & 112 & 50.5 \\
\hline Government service & 64 & 28.8 \\
\hline Private service & 46 & 20.7 \\
\hline Mother's educational status & & \\
\hline Literate & 205 & 92.3 \\
\hline Illiterate & 17 & 7.7 \\
\hline Mother's level of education(n $=205)$ & & \\
\hline Basic level & 36 & 17.6 \\
\hline Secondary level & 121 & 59.0 \\
\hline Bachelor and above & 48 & 23.4 \\
\hline Mother's occupation & & \\
\hline Self employed & 179 & 80.6 \\
\hline Government service & 20 & 9.0 \\
\hline Private service & 23 & 10.4 \\
\hline
\end{tabular}

In table 3, majority of the participants $(65.3 \%)$ had not known about male nurse, more than half $(64.9 \%)$ did not have nurse in a family. Regarding choosing occupation $25.7 \%$ considered doctor as a profession followed by $17.6 \%$ in health field and $14.4 \%$ as nurse by profession. [Table 3]

Table 3. Respondents' General Information $n=222$

\begin{tabular}{|l|l|l|}
\hline Variables & Frequency & Percentage \\
\hline know a nurse who is male & & \\
\hline Yes & 77 & 34.7 \\
\hline No & 145 & 65.3 \\
\hline family members as a nurse in family & & \\
\hline Yes & 78 & 35.1 \\
\hline No & 144 & 64.9 \\
\hline Considering occupation & & \\
\hline Agriculture & 18 & 8.1 \\
\hline Doctor & 57 & 25.7 \\
\hline Engineering & 29 & 13.1 \\
\hline Health Field & 39 & 17.6 \\
\hline Not decided & 23 & 10.4 \\
\hline Nurse & 32 & 14.4 \\
\hline Others & 24 & 10.8 \\
\hline
\end{tabular}

Regarding item wise distribution, majority of the students agreed on the statements like" Nursing is totally a female profession so I don't want to see men in nursing" $(87.8 \%)$, Nursing is only the feminine profession" (79.75\%)," inappropriateness for males to work with females" (79.5\%), male can take full responsibility in an emergency situation (77.4\%). However, considerable proportion of the students was unbiased on the statements like "I believe all the male nurses is considered Gay" (46.4\%), "I believe male nurses would be respected more than female nurses" (41.4\%). Furthermore, majority of the students' showed disagreement on the statements like "Nursing profession should encourage the entry of men"( $93.7 \%$ ), "I believe male nurses should be included as a backbone in health care delivery system"( $86.5 \%)$, "Men are appropriate for combative and abusive patients"(68.1\%)," The presentation by the mass media as being more suited for women discourages men from choosing as a nursing career " $(68 \%)$ [Table 4]

Table 4. Item Wise Description of the Perception towards Enrolment of Male in Nursing $\mathbf{n}=222$

\begin{tabular}{|l|l|l|l|l|l|l|}
\hline S.N. & Items & $\begin{array}{l}\text { Strongly } \\
\text { Disagree } \\
\text { No. }(\%)\end{array}$ & $\begin{array}{l}\text { Disagree } \\
\text { No. }(\boldsymbol{\%})\end{array}$ & $\begin{array}{l}\text { Neutral } \\
\text { No. }(\boldsymbol{\%})\end{array}$ & $\begin{array}{l}\text { Agree } \\
\text { No. }(\boldsymbol{\%})\end{array}$ & $\begin{array}{l}\text { Strongly } \\
\text { Agree } \\
\text { No. }(\boldsymbol{\%})\end{array}$ \\
\hline 1. & $\begin{array}{l}\text { I believe that nursing is not perceived as a very masculine } \\
\text { career for males to pursue in our society }\end{array}$ & $29(13.1)$ & $75(33.8)$ & $32(14.4)$ & $45(20.3)$ & $41(18.5)$ \\
\hline 2. & $\begin{array}{l}\text { I feel that nursing is more appropriate for female because they } \\
\text { tend to be more caring and compassionate than male }\end{array}$ & $52(23.4)$ & $75(33.8)$ & $59(26.6)$ & $21(9.5)$ & $15(6.8)$ \\
\hline
\end{tabular}


Ramesh Subba et.al. Perception towards male enrolment in nursing among high school students at selected schools of Bharatpur, Chitwan.

\begin{tabular}{|c|c|c|c|c|c|c|}
\hline \multicolumn{7}{|c|}{ Table 4 Continued... } \\
\hline 3. & $\begin{array}{l}\text { The current presentation by the mass media as being more } \\
\text { suited for women discourages men from choosing as a } \\
\text { nursing career }\end{array}$ & $61(27.5)$ & $90(40.5)$ & $31(14.0)$ & $32(14.4)$ & $8(3.6)$ \\
\hline 4. & $\begin{array}{l}\text { I would encourage a male family member to follow nursing } \\
\text { as a challenging and rewarding career choice }\end{array}$ & $72(32.4)$ & $83(37.4)$ & $51(23.0)$ & $10(4.5)$ & $6(2.7)$ \\
\hline 5 & I believe Nursing is only the feminine profession & $15(6.8)$ & $8(3.6)$ & $22(9.9)$ & $80(36.0)$ & 97(43.7) \\
\hline 6. & $\begin{array}{l}\text { I believe that only male can take full responsibility in an } \\
\text { emergency situation }\end{array}$ & $6(2.7)$ & $9(4.1)$ & $35(15.8)$ & $82(36.9)$ & $90(40.5)$ \\
\hline 7. & $\begin{array}{l}\text { I believe the quality of patient care will increase when men } \\
\text { enters nursing }\end{array}$ & $14(6.3)$ & $61(27.5)$ & $89(40.1)$ & $40(18.0)$ & $18(8.1)$ \\
\hline 8. & $\begin{array}{l}\text { Nursing is totally a female profession so I don't want to see } \\
\text { men in nursing }\end{array}$ & $7(3.2)$ & $5(2.3)$ & $15(6.8)$ & $74(33.3)$ & $121(54.5)$ \\
\hline 9. & I believe male can tolerate more pressure than female & $29(13.1)$ & $56(25.2)$ & $59(26.6)$ & $52(23.4)$ & $26(11.7)$ \\
\hline 10. & I believe male can work on ward which requires strength & $32(14.4)$ & $104(46.8)$ & $54(24.3)$ & $20(9.0)$ & $12(5.4)$ \\
\hline 11. & $\begin{array}{l}\text { I believe male entering the nursing can pose a threat to the } \\
\text { controlling in nursing profession for female }\end{array}$ & $9(4.1)$ & $28(12.6)$ & $74(33.3)$ & $71(32.0)$ & $40(18.0)$ \\
\hline 12. & $\begin{array}{l}\text { I believe patient regardless of gender would not trust and } \\
\text { accept male nurse in society }\end{array}$ & $14(6.3)$ & $46(20.7)$ & $62(27.9)$ & $68(30.6)$ & $32(14.4)$ \\
\hline 13. & $\begin{array}{l}\text { I believe the quality of patient care will increase when men } \\
\text { enter the nursing profession }\end{array}$ & $19(8.6)$ & $82(36.9)$ & $70(31.5)$ & $34(15.3)$ & $17(7.7)$ \\
\hline 14. & Men are appropriate for combative and abusive patients & $29(13.1)$ & $100(45.0)$ & $51(23.0)$ & $25(11.3)$ & $17(7.7)$ \\
\hline 15 & Nursing profession should encourage the entry of men & $101(45.5)$ & $107(48.2)$ & $9(4.1)$ & $3(1.4)$ & $2(0.9)$ \\
\hline 16 & Men can be threat to the progression in female nurses career & $6(2.7)$ & $36(16.2)$ & $50(22.5)$ & $78(35.1)$ & $52(23.4)$ \\
\hline 17 & $\begin{array}{l}\text { I believe it is a gender biases and discrimination against men } \\
\text { in nursing as a profession }\end{array}$ & $40(18.0)$ & $66(29.7)$ & $49(22.1)$ & $48(21.6)$ & 19(8.6) \\
\hline 18 & $\begin{array}{l}\text { I believe male nurses should be included as a backbone in } \\
\text { health care delivery system }\end{array}$ & $46(29.7)$ & $126(56.8)$ & $34(15.3)$ & $9(4.1)$ & $7(3.2)$ \\
\hline 19 & $\begin{array}{l}\text { I believe the role of nurses like bathing, cleaning feeding and } \\
\text { medication administration is entirely a suitable work of } \\
\text { female nurses }\end{array}$ & $27(12.2)$ & $49(22.1)$ & $54(24.3)$ & $56(25.2)$ & $36(16.2)$ \\
\hline 20. & I believe it is inappropriate for males to work with females & $6(2.7)$ & $16(7.2)$ & $23(10.4)$ & $87(39.2)$ & $90(40.5)$ \\
\hline 21. & $\begin{array}{l}\text { The duties and responsibilities in nursing is entirely female } \\
\text { oriented }\end{array}$ & $3(1.4)$ & $20(9.0)$ & $49(22.1)$ & $89(40.1)$ & $61(27.5)$ \\
\hline 22 & I believe all the male nurses is considered Gay & $21(9.5)$ & $58(26.1)$ & $103(46.4)$ & $32(14.4)$ & $8(3.6)$ \\
\hline 23. & $\begin{array}{l}\text { I believe male nurses would be respected more than female } \\
\text { nurses }\end{array}$ & $9(4.1)$ & $18(8.1)$ & 92(41.4) & 64(28.8) & $39(17.6)$ \\
\hline 24. & $\begin{array}{l}\text { High level of knowledge, skills and sound character are keys } \\
\text { to became a nurse which is suitable for the males }\end{array}$ & $23(10.4)$ & $73(32.9)$ & $67(30.2)$ & $36(16.2)$ & $23(10.4)$ \\
\hline 25. & I believe men would be considered as assistance to doctors & $39(17.6)$ & $106(47.7)$ & $48(21.6)$ & $20(9.0)$ & $9(4.1)$ \\
\hline 26. & $\begin{array}{l}\text { Role ambiguity between male nurses and doctors can bring } \\
\text { the dissatisfaction for males towards the nursing as a career }\end{array}$ & $16(7.2)$ & $37(16.7)$ & $85(38.3)$ & $65(29.3)$ & $19(8.6)$ \\
\hline 27. & $\begin{array}{l}\text { I believe it is easy for male nurses to get secure job } \\
\text { opportunities }\end{array}$ & $25(11.3)$ & $65(29.3)$ & $83(37.4)$ & $36(16.2)$ & $13(5.9)$ \\
\hline 28. & Male nurses can get the job easily than females in abroad & $28(12.6)$ & $54(24.3)$ & 74(33.3) & $48(21.6)$ & $18(8.1)$ \\
\hline
\end{tabular}

Table 5. Respondents' Level of Perception towards Male Enrolment in Nursing

\begin{tabular}{|l|l|l|}
\hline Level of perception & Frequency & Percentage \\
\hline Positive perception $\geq$ median $(84)$ & 121 & 54.5 \\
\hline Negative perception <median (84) & 101 & 45.5 \\
\hline Total & 222 & 100.0 \\
\hline
\end{tabular}

Out of 222 participants, more than half $(54.5 \%)$ had positive perception towards male enrolment in nursing whereas less than half $(45.5 \%)$ had negative perception towards male enrolment in nursing [Table 5]

In table 6 , the level of perception towards male enrolment was not significantly associated with respondents' socio- demographic variables

Table 6. Association between Level of Perception towards Male Enrolment in Nursing and Respondents' Socio demographic Variables

\begin{tabular}{|c|c|c|c|c|}
\hline \multirow[t]{2}{*}{ Variables } & \multicolumn{2}{|l|}{ Level of Perception } & \multirow[t]{2}{*}{$\chi^{2}$} & \multirow[t]{2}{*}{ p value } \\
\hline & positive perception No. (\%) & Negative perception No. (\%) & & \\
\hline \multicolumn{5}{|c|}{ Age (in completed years) } \\
\hline$<17 \mathrm{yrs}$ & $23(52.3)$ & $21(47.7)$ & 0.110 & 0.740 \\
\hline$\geq 17 \mathrm{yrs}$ & $98(55.1)$ & $80(44.9)$ & & \\
\hline \multicolumn{5}{|l|}{ Sex } \\
\hline Male & $47(50.5)$ & $46(49.5)$ & 1.016 & 0.314 \\
\hline Female & $74(57.4)$ & $55(42.6)$ & & \\
\hline \multicolumn{5}{|l|}{ Religion } \\
\hline Hindu & $111(54.7)$ & $92(45.3)$ & 0.029 & 0.864 \\
\hline Other than Hindu & $10(52.6)$ & $9(47.4)$ & & \\
\hline
\end{tabular}


Ramesh Subba et.al. Perception towards male enrolment in nursing among high school students at selected schools of Bharatpur, Chitwan.

\begin{tabular}{|c|l|l|l|l|}
\hline \multicolumn{2}{|c|}{ Table 6 Continued... } & & \\
\hline Types of School & \multicolumn{2}{|c|}{} & 4.22 & 0.516 \\
\hline Private & $57(52.3)$ & $52(47.7)$ & & \\
\hline Government & $64(56.6)$ & $49(43.4)$ & & \\
\hline Standard & & & 2.150 & 0.143 \\
\hline $11^{\text {th }}$ standard & $31(47.0)$ & $35(53.0)$ & & \\
\hline $12^{\text {th }}$ standard & $90(57.7)$ & $66(42.3)$ & & \\
\hline Place of residence & & & 0.172 & 0.918 \\
\hline Rural Municipality & $11(57.9)$ & $8(42.1)$ & & \\
\hline Municipality/Sub Municipality & $23(56.1)$ & $18(43.9)$ & & \\
\hline Metropolitan/Sub Metropolitan city & $87(53.7)$ & $75(46.3)$ & \\
\hline
\end{tabular}

Table 7 shows that the level of perception towards male enrolment was not significantly associated with respondents' parents' related information.

Table 7. Association between Level of Perception towards Male Enrolment in Nursing and Respondents' Parents Information

\begin{tabular}{|c|c|c|c|c|}
\hline \multirow{2}{*}{ Variables } & \multicolumn{2}{|l|}{ Level of Perception } & \multirow[t]{2}{*}{$\chi^{2}$ value } & \multirow[t]{2}{*}{ p- value } \\
\hline & Good perception No. (\%) & Poor perception No. (\%) & & \\
\hline Father's educational status & & & - & 1.000 \\
\hline Literate & $117(54.7)$ & $97(45.3)$ & & \\
\hline Illiterate & $4(50.0)$ & $4(50.0)$ & & \\
\hline \multicolumn{5}{|l|}{ Mother's educational status } \\
\hline Literate & $114(55.6)$ & 91(44.4) & 1.319 & 0.251 \\
\hline Illiterate & $7(41.2)$ & $10(58.8)$ & & \\
\hline \multicolumn{5}{|l|}{ Mothers' occupation } \\
\hline Self employed & $97(54.2)$ & $82(45.8)$ & & \\
\hline Government service & $8(40.0)$ & $12(60.0)$ & 3.808 & 0.149 \\
\hline Private service & $16(69.6)$ & $7(30.4)$ & & \\
\hline \multicolumn{5}{|l|}{ Know a nurse who is male } \\
\hline Yes & $43(55.8)$ & $34(44.2)$ & 0.085 & 0.770 \\
\hline No & $78(53.8)$ & $67(46.2)$ & & \\
\hline \multicolumn{5}{|l|}{ Nurse in a family } \\
\hline Yes & $42(53.8)$ & $36(46.2)$ & 0.021 & 0.885 \\
\hline No & $79(54.9)$ & $65(45.1)$ & & \\
\hline
\end{tabular}

\section{DISCUSSION}

Nursing is an important part of the health care system due to the importance of care and nurture that it holds for the needy. Retaining male students in adopting career in nursing is challenging in reality and the steps have already been taken by allocating the seats for male in nursing in line with the country's policy of main streaming gender equality in every sector. However, despite the growing trend of a demand for nurses, worldwide it is still a profession that is largely dominated by women with various conflicting perception especially among the high school students. Hence, it has been a great concern to all the education authorities in bringing the change in nursing profession.

We found that majority of the participants $(65.3 \%)$ were unknown about the nurse who is a male, more than half $(64.9 \%)$ did not have nurse in a family. Majority $(25.7 \%)$ considered doctor as a profession followed by $17.6 \%$ in health field and $14.4 \%$ as nurse by profession. Our finding regarding the consideration of other profession other than nursing is consistent with the finding reported in USA where male students' represented nursing as a second career while majority were likely to consider profession such as physical therapist and military. ${ }^{16}$ Similarly, MP Maloni, (1995) reported that majority $78.6 \%$ did not view nursing as a career preference while only $8.6 \%$ high school students' responded nursing as a career option. ${ }^{17}$ This might be attributed to the fact that there might be vast array of career opportunities with regards to choosing a profession which might decrease the interest among high school students in nursing.

Nepal has a male dominant culture and nursing is primarily a female dominant profession which practiced by women and males who are practicing nursing are very few. Majority of our students agreed that Nursing is totally a female profession so they don't want to see men in nursing. Other 
studies have pointed out that nursing is mainly for girls and every nursing class is dominated by the girls. ${ }^{18-20}$ Our students also had good agreement with the statement that "Nursing is only the feminine profession and it is inappropriate for males to work with females. Studies from various part of the world had showed that nursing is considered as a female profession and females tends to disagree that males are better suited to nursing than women. ${ }^{14,21-24}$ In addition, Bartfay (2016) found that nursing was more appropriate for females because of their caring and compassionate nature compared to males. ${ }^{25}$ Evidences have been variable, with the reports of nursing as men's work 26,27 and students' viewed nursing as a masculine work despite of the contradiction to the stereotypical image of nursing in society. ${ }^{28}$ Likewise, Keshk et al. $(2016)^{29}$ and Varaei S, $(2012)^{30}$ gave a contradictory view with a belief that nursing is a career suitable for both the genders. The variation however, can be due to the different career choices among the genders across various countries. Therefore, gender stereotyping is common in the nursing field which undermines the potential development of men in nursing despite of the necessary steps taken by governing bodies to increase the number of male nursing students and practicing male nurses lately.

The present study finding also resonates with the previous literatures which attributed that male can take full responsibility in an emergency situation. ${ }^{31,32}$ This might be attributed to the fact that male nurses might get more support from the male physicians which fosters their ability to succeed in working into technical areas. Furthermore, almost all of the students disagreed that "Nursing profession should encourage the entry of men "which is in contrast with the study in USA which showed that the vast majority of female nurses have positive attitudes toward the male nurse and felt more males should be encouraged to enter nursing. ${ }^{33}$ Since there is no exact evidence to the resistance of male entry into nursing, the "sex-typing" of nursing is undoubtedly might be due to social, cultural and economic values that provide disincentives for males to enter this traditionally female occupation. Likewise, majority of the students disagreed that Male nurses are appropriate for combative and abusive patients which is in the line with the study which found that male nurses were uncomfortable with the assignments with the violent and unruly patients. ${ }^{34}$ Dissimilarity to the thought, various studies have pointed out that male nurses were gravitated toward positions suitable to their masculine nature when assigned with unruly or potentially violent patients. ${ }^{35,23}$ The difference in findings support the notion that each work culture creates a gender role expectation based on the beliefs from the individuals within each system.

Present study revealed that more than half $(52.3 \%)$ students had good perception towards male enrolment in nursing which is consistent with the finding of the study conducted in Nigeria which revealed that more than half $(53 \%)$ senior secondary students held a positive perception towards nursing as a career choice for men. ${ }^{26}$ Similarly, (Hasan, 2020) gave a contradictory view that stigma of nursing profession is suitable only for women and men are not favourable in considering nursing as their career choice. ${ }^{14}$ On the other hand, present study resonates with the finding of study which reported no significant association between perception of male enrolment with various sociodemographic variables 26 whereas, inconsistent finding conducted in Nigeria revealed the significant association between male and female attitudes towards nursing as a career for men. ${ }^{36}$ One possible explanation for the variations in view across the various countries might be due to the societal expectations and stigma regarding the career choices for both genders. Therefore, if nursing is serious in its ambition to hire and retain male nurses despite the given derogatory perceptions of men in nursing, more dialogue and actions 
need to be implemented to diversify the profession.

This research adds value to the existing literature, through detailed analysis of students' perception towards male enrolment in nursing. It also provides some important insights into how male nurses can be increased in developing countries like Nepal. In between positive and negative images of gender based nursing profession in Nepalese society, confronting a debate that should be resolved in the next few years and health care systems must contribute to emphasize the constructive side for retaining the male nurses in the field considering the various factors. Firstly, there is an urgent need in setting the plan encompassing high school, media and governing bodies to improvise the consideration of both males and females in nursing profession. Secondly, clarifying the role identity of the graduates under different titles but with the same jobs will help both the public and students to accept nursing as a male career. These factors, if positively entertained, will result in the growth of male nurses in our country in the coming decade. Our study has certain limitations. The subjects of this study were from few selected colleges, limiting the generalization of our findings. The use of interviews is encouraged in future studies to draw a more comprehensive assessment. This study could have yielded better results if longitudinal study has been performed.

\section{CONCLUSION}

Our county has adopted the inclusion of male nurses to improve the status of nursing to remove the view of gender constraint profession in nursing. Student's perception regarding the male enrolment is an important factor for the effective outcome in the health care. The study aimed to synthesize the perception of male enrolment in nursing among high school students at Chitwan District in Nepal. We found that more than half of the students showed positive perception towards male enrolment in nursing and we also found that majority of students agreed that nursing was feminine profession and appropriate for females and almost all of the students disagreed that they would encourage male in nursing. Therefore, there is a need for secondary students to be aware of what nursing as a profession entails and that gender is not a determining factor of being a better nurse.

\section{ACKNOWLEDGMENTS}

Researchers are very grateful to Chitwan Medical College-Institutional Research Committee for providing opportunity to conduct the research. We owe our sincere gratitude to principal of Narayani Namuna Madhyamik Bidhyalaya and Balmiki Sikshya Sadhan. We are also delighted to all the respondents of our study for their voluntary participation.

\section{Acknowledgement: None}

Conflict of Interest: None

\section{Source of Funding: None}

\section{Ethical Approval: Approved}

\section{REFERENCES}

1. Wolfenden J. Men in Nursing. The Internet Journal of Allied Health Sciences and Practice. 2011 Apr 01;9(2), Article 5.[FULL TEXT]

2. Brodie DA, Andrews GJ, Andrews JP, Thomas GB, Wong J, Rixon L. Perceptions of nursing: confirmation, change and the student experience. Int J Nurs Stud. 2004 Sep;41(7):721-33.[DOI][PUBMED]

3. De Cooman R, De Gieter S, Pepermans R, Du Bois C, Caers R, Jegers M. Freshmen in nursing: job motives and work values of a new generation. J Nurs Manag. 2008 Jan;16(1):56-64.[DOI][PUBMED][FULL TEXT]

4. Ashkenazi L, Livshiz-Riven I, Romem P, Grinstein-Cohen O. Male Nurses in Israel: Barriers, Motivation, and How They Are Perceived by Nursing Students. J Prof Nurs. 2017 Mar - Apr;33(2):1629.[DOI][PUBMED][ABSTRACT] 
5. GE AE, El Hawashy ZI, AA GE, Taha EE. Undergraduate male nursing students' perception about the image of the nursing profession. Journal of American science. 2011;7(3):614-23.[FULL TEXT]

6. Roth JE, Coleman CL. Perceived and real barriers for men entering nursing: implications for gender diversity. J Cult Divers. 2008;15(3):14852.[PUBMED][LINK]

7. Barrett-Landau S, Henle S. Men in Nursing: Their Influence in a Female Dominated Career. Journal for Leadership and Instruction. 2014;13(2):10-3.[FULL TEXT]

8. Zamanzadeh V, Valizadeh L, Negarandeh R, Monadi M, Azadi A. Factors influencing men entering the nursing profession, and understanding the challenges faced by them: Iranian and developed countries' perspectives. Nurs Midwifery Stud. 2013 Dec;2(4):49-56.[DOI][PUBMED]

9. Prasai B. (2019). Man and nurse. The Annapurna Express. [LINK]

10. Karabacak Ü, Uslusoy E, Alpar ŞE, Bahçecik N. Image of nursing held by nursing students according to gender: a qualitative study. Int J Nurs Pract. 2012 Dec;18(6):537-44.DOI][PUBMED]

11. Edusanjal. (2018).Nepal Nursing Council decides to allow male students to study nursing[LINK]

12. Global press journal. (2019).Nepal's Nursing Colleges Reserve Spots for Male Students[LINK]

13. Hasan MK, Jusoh NS, Hamid SH, Nurumal MS. Perceptions toward Considering Nursing as A Career Choice among Secondary School Students. Jurnal Keperawatan Indonesia. 2020 Dec 1;23(3):194-201.[DOI][LINK]

14. Ibrahim AF, Akel DT, Alzghoul HW. Image of Nursing Profession as Perceived by Egyptian and Jordanian Undergraduate Male Nursing Students: A Comparative Study. Journal of Education and Practice. 2015;6(14):24-36.[FULL TEXT]

15. Rajesh K, Sharma SK, Meena BS. High School Students' Perception of Nursing as A Career-A Pilot Survey. The Journal of Nursing Trendz. 2017;8(2):6-10.[LINK]

16. Conner BT, Anderson BS, Matutina R. Exploring the perceptions of male nursing students enrolled in an accelerated baccalaureate degree nursing program.
Journal of Nursing Education and Practice. 2016;6(8):30-5.[DOI][FULL TEXT]

17. Maloney MP.High school students' perceptions of nursing as a career choice (Doctoral dissertation, University of British Columbia);1995 [DOI][FULL TEXT]

18. Cui N, Wang R, Song F, Jin J. Experiences and perceptions of male nursing students in a single-sex class: A qualitative descriptive study. Nurse Educ Pract. 2021 Feb;51:102996.[DOI][PUBMED]

19. Bartfay WJ, Bartfay E, Clow KA, Wu T. Attitudes and perceptions towards men in nursing education. Internet journal of allied health sciences and practice. 2010;8(2):6.[FULL TEXT]

20. Liaw SY, Wu LT, Chow YL, Lim S, Tan KK. Career choice and perceptions of nursing among healthcare students in higher educational institutions. Nurse Educ Today. 2017 May;52:66-72[DOI].[PUBMED]

21. Abudari MO, Ibrahim AF, Aly AA. Men in nursing" as viewed by male students in secondary schools. Clin Nurs Stud. 2016;4(2):41-7[DOI][FULL TEXT]

22. Jan A, Sikander S. Perceptions of high school students about nursing as a career. Rawal Medical Journal. 2012;37(1):137.[FULL TEXT]

23. Ozdemir A, Akansel N, Tunk GC. Gender And Career: Female And Male Nursing Students'perceptions Of Male Nursing Role In Turkey. Health science journal. $2008 \mathrm{Jul}$ 1;2(3).[FULL TEXT]

24. Mohamed HE, El-Nemer AM. The Experience of newly enrolled Egyptian male nursing students into maternity nursing curriculum. Life Science Journal. 2013;10(1):2810-5.[LINK]

25. Bartfay WJ, Bartfay E. The lived experiences of male nursing students in Ontario, Canada: Implications for nursing education and practice in the new millennium. $2016 \mathrm{Jul}$ 4330: 255-262[LINK]

26. Folami FF. Assessment of knowledge and perception of senior secondary school students towards nursing as a career choice for men in selected local government of Lagos State, Nigeria. Texila Int J Nurs. 2018;4:1-9.[LINK]

27. GE AE, El Hawashy ZI, AA GE, Taha EE. Undergraduate male nursing students' perception about the image of the nursing 
Ramesh Subba et.al. Perception towards male enrolment in nursing among high school students at selected schools of Bharatpur, Chitwan.

profession. Journal of American science. 2011;7(3):614-23.[LINK]

28. Price SL. The experience of choosing nursing as a career: narratives from millennial nurses. Toronto: (Doctoral dissertation; University of Toronto) 2011.[FULL TEXT]

29. Keshk LI, Mersal FA, Al Hosis KF. Preparatory students' perception about the nursing profession and its impact on their career choice in Qassim University in KSA. American Journal of Nursing Research. 2016;4(3):74-82. [DOI][FULL TEXT]

30. Varaei S, Vaismoradi M, Jasper M, Faghihzadeh S. Iranian nurses selfperception - factors influencing nursing image. J Nurs Manag. 2012;20(4):551-60. [DOI][PUBMED]

31. Stott A. Exploring factors affecting attrition of male students from an undergraduate nursing course: a qualitative study. Nurse Educ Today. 2007;27(4):325-32.[DOI] [PUBMED]

32. Ellis DM, Meeker BJ, Hyde BL. Exploring men's perceived educational experiences in a baccalaureate program. $J$ Nurs Educ. 2006;45(12):523-7. [DOI][PUBMED]
33. Fottler MD. Attitudes of female nurses toward the male nurse: a study of occupational segregation. J Health Soc Behav. 1976 Jun;17(2):98-110. [LINK][PUBMED]

34. LaRocco SA. A grounded theory study of socializing men into nursing. The Journal of Men's Studies. 2008 Mar;15(2):1209.[LINK]

35. Evans J, Frank B. Contradictions and tensions: Exploring relations of masculinities in the numerically femaledominated nursing profession. The Journal of Men's Studies. 2003 Jun;11(3):27792.[LINK]

36. Ebosetale AR, Mustafa-Shaibu M. Masculinity in the Nursing Profession: Adolescent Attitudes towards Nursing as a Career Choice for Men in Benin City, Edo State, Nigeria.(2017)[ FULL TEXT]

How to cite this article: Subba R, Subba HK, Joshi A et.al. Perception towards male enrolment in nursing among high school students at selected schools of Bharatpur, Chitwan. Int J Health Sci Res. 2021; 11(11): 7886. DOI: https://doi.org/10.52403/ijhsr. 20211109 